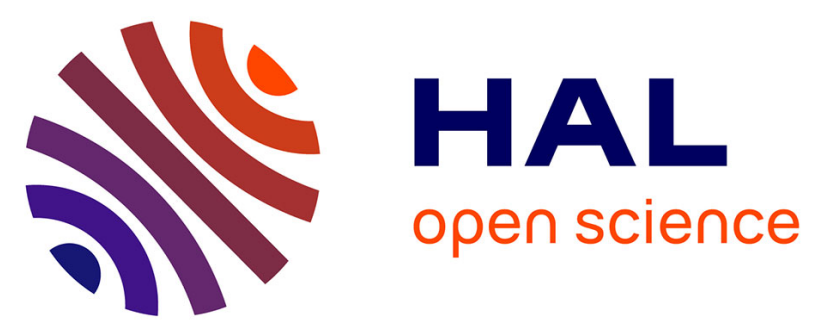

\title{
Interannual variations of radiometric time profile and crop yield: coupling of functional model and short wavelength remote sensing observations
}

\author{
Sophie Moulin, A. Fischer, Gérard Dedieu
}

\section{- To cite this version:}

Sophie Moulin, A. Fischer, Gérard Dedieu. Interannual variations of radiometric time profile and crop yield: coupling of functional model and short wavelength remote sensing observations. IEEE International Geoscience and Remote Sensing Symposium (IGARSS), Institute of Electrical and Electronics Engineers (IEEE). USA., Jul 1995, Florance, Italy. 10.1109/IGARSS.1995.521782 . hal-02778224

HAL Id: hal-02778224

https://hal.inrae.fr/hal-02778224

Submitted on 4 Jun 2020

HAL is a multi-disciplinary open access archive for the deposit and dissemination of scientific research documents, whether they are published or not. The documents may come from teaching and research institutions in France or abroad, or from public or private research centers.
L'archive ouverte pluridisciplinaire HAL, est destinée au dépôt et à la diffusion de documents scientifiques de niveau recherche, publiés ou non, émanant des établissements d'enseignement et de recherche français ou étrangers, des laboratoires publics ou privés. 
1995 International Geoscience and Remote Sensing Symposium

Firenze, Italy - July 10-14, 1995

Topic : Applications of remote sensing (crop and forest monitoring and classification)

\title{
INTERANNUAL VARIATIONS OF RADIOMETRIC TIME PROFILE AND CROP YIELD : \\ COUPLING OF FUNCTIONAL MODEL AND SHORT WAVELENGTH REMOTE SENSING OBSERVATIONS.
}

\author{
S. Moulin, A. Fischer and G. Dedieu
}

LERTS/CESBIO

bpi 2801 - 18, avenue E. Belin - 31055 Toulouse Cedex - France

Tel : (33) 61558519 - Fax : (33) 61558500 - e-mail : sophie.moulin@cesbio.cnes.fr

Studies concerning monitoring of crop covers and yield forecasting have shown the great interest of the linkage of production models with satellite measurements. Mechanistic crop models allow a good description of the matter and energy exchanges of vegetation with soil and atmosphere. The study concerns the largest French agricultural region where many environmental factors and initial conditions can be controlled.

The first purpose of this paper is to reproduce the temporal profile of radiometric signal that can be observed from satellite. Since we need frequent data, we use low spatial resolution data over a region where one crop is largely represented (winter cereal). A crop growth model (AFRCWHEAT from Porter et al., 92) is used for the predominant crop and empirical time profiles for other groups. Here, the reflectance time profile is modelled in the direct way : a radiative transfer model is coupled with a vegetation functioning model through the leaf area index in order to predict radiometric signal given by satellite remote sensing. Reflectances are predicted for 3 successive years over the same region. Then we check if the phenological calendar and reflectances are well reproduced through a comparison with NOAA/AVHRR observations.

The second purpose of this paper is to test a technique of satellite data assimilation into a functional model, in order to adjust initial conditions or pertinent parameters, over fields of winter wheat for 3 successive years. We use the assimilation of high spatial resolution satellite data (SPOT/HRV) into the coupled crop growth/radiative transfer model. A sensitivity study is performed to evaluate the influence of the choice and the parameterization of the reflectance model. The final objective is to verify if initial conditions retrieved from satellite measurements are in accordance with ground knowledge. By the same way, we compare crop productions predicted with the adjusted model and yields evaluated by agricultural services for 3 years.

At field scale, the relevance of the methodology is limited by the small number of high spatial resolution pictures for a vegetative period. So the application of this methodology with low spatial resolution data will be of great interest, provided that the regional radiometric signal is well reproduced. 